J. Appl. Glycosci., 56, 281-286 (2009)

(C) 2009 The Japanese Society of Applied Glycoscience

Regular Paper (in Japanese with English Abstract)

\title{
Production and Properties of Low-malt Beer Using Extremely Fine Potato Starch
}

(Received March 6, 2009; Accepted July 24, 2009)

\author{
Atsushi Tsukamoto, ${ }^{1}$ Michihiro Fukushima, ${ }^{2}$ Toshio Nagashima, ${ }^{3}$ Naoto Hashimoto, ${ }^{4}$ \\ Katsuichi Saito ${ }^{4}$ and Takahiro Noda,* \\ ${ }^{1}$ Tokachi Beer Inc. (9-6, Minami, West-1-jo, Obihiro 080-0011, Japan) \\ ${ }^{2}$ Obihiro University of Agriculture and Veterinary Medicine (11, Nishi-2-sen, Inada-cho, Obihiro 080-8555, Japan) \\ ${ }^{3}$ Department of Food Science and Technology, Faculty of Bioindustry, Tokyo University of Agriculture \\ (196, Yasaka, Abashiri 099-2493, Japan) \\ ${ }^{4}$ Memuro Upland Farming Research Station, National Agricultural Research Center for Hokkaido Region \\ (4, Minami-9-sen, Shinsei, Memuro-cho, Kasai 082-0081, Japan)
}

\begin{abstract}
To manufacture low-malt beer using potato starch, we selected the potato starch suited for low-malt beer brewing from several potato starches. Moreover, the componential and functional characteristics of the low-malt beer obtained thus were evaluated. As extremely fine potato starch obtained by air-classification (median size $13.6 \mu \mathrm{m}$ ) had high phosphorus content but low peak viscosity of Rapid Visco Analyser (RVA), we regarded it as the most suitable material for low-malt beer brewing of the 10 potato starches examined. Phosphoryl-oligosaccharides, which are obtainable after digestion of a starch with phosphate, were obviously found $(600 \mathrm{ppm})$ in low-malt beer using such potato starch. In contrast, no or very little phosphoryloligosaccharide was found in low-malt beers using corn or sweet potato starches. Thus, novel type functional low-malt beer would be manufactured by using extremely fine potato starch.
\end{abstract}

Key words: low-malt beer, extremely fine potato starch

\author{
極小粒子馬鈴薯澱粉を利用した発泡酒の製造と性質

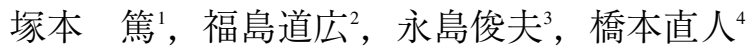 \\ 齋藤勝一 ${ }^{4}$, 野田高弘, ${ }^{4, *}$ \\ 1 十勝ビール株式会社 (080-0011 帯広市西 1 条南 9 丁目 6 番) \\ 2 国立大学法人带広畜産大学 (080-8555 带広市稲田町西 2 線 11 番地) \\ 3 東京農業大学生物産業学部 (099-2493 網走市八坂 196 番地) \\ 4 独立行政法人農業食品産業技術総合研究機構北海道農業研究センター芽室研究拠点 \\ (082-0081 北海道河西郡芽室町新生南 9 線 4 番地)
}

ビールは，麦芽，ホップ，水を発酵させたもの $(100 \%$ 麦芽ビール)，または，麦芽，ホップ，水に政令で定めら れた澱粉または澱粉質作物を副原料として加えて発酵させ たものである。ただ，その原料中における副原料の重量 が麦芽の重量の 2 分の 1 を超えないものに限られていて, 超えるものは発泡酒として定義されている. 副原料の種類 の違いによりビールや発泡酒の成分や風味が変化するもの と考えられるが, 現状では, 分離した澱粉ではコーンス ターチが, 澱粉質原料では, 米, コーングリッツがおもに 用いられ，他の副原料はほとんど用いられていない。一 方，副原料に地域の農作物を用いることでビールや発泡酒 の個性や付加価值を付与したり，地域の特徵を出すことが できるようになるとともに，地域農業・食品工業の活性に つながる可能性がある。 また，消費者の健康志向の高まり

\footnotetext{
${ }^{*}$ Corresponding author $($ Tel. $+81-155-62-9278$, Fax. $+81-155-62-$ 2926, E-mail: noda@affrc.go.jp).
}

を受けて，種々の機能性を付与したビールや発泡酒が開発 されている。

馬鈴薯は澱粉含量が 15-20\% と高く，すでに従来から馬 鈴著澱粉を分離する方法が工業的に確立されている。北海 道では道東地域を中心に澱粉原料用の馬鈴薯が作付けさ れ，年間約 20 万トンの馬鈴薯澱粉が生産されている。澱 粉原料用の馬鈴薯品種の作付面積は，平成 18 年度におい てはコナフブキが $86.7 \%$ と断然高い割合を占め，次いで 紅丸が $5.7 \%$ を占めており，残りはアーリースターチ，ア スタルテ，エニワ，サクラフブキとなっている。ここ数年 は，馬鈴著澱粉の価格が下落傾向にあるため，緊急な対策 が求められている.ビール・発泡酒は主要加工食品の中で 最も生産量が多く, 平成 19 年で 630 万 $\mathrm{kL}$ にも達してい る.ビール・発泡酒生産の副原料として，分離された澱粉 ではコーンスターチ以外の澱粉はほとんど用いられていな い. 馬鈴薯澱粉は，大量入手が容易であり，コストも安い ため, ビールや発泡酒の有望な副原料の一つと考えられる. 
馬鈴薯澱粉は，グルコース糖鎖中にエステル結合したリ ン酸基が，リン含量換算で $500 \mathrm{ppm}$ 以上と，他の澱粉よ り明らかに多く存在する1).また，馬鈴薯澱粉の粒子径は 2-100 $\mu \mathrm{m}$ と，他の澱粉の粒子径と比べて大きく幅が広い ことが知られている.さらに, 馬鈴薯澱粉は, 他の澱粉と 比べ粘度が高いことも知られている．馬鈴薯品種間で澱粉 中のリン含量, 粘度等の特性にかなりの差異があり, エニ ワやホッカイコガネが高リン・高粘度, 紅丸や農林 1 号が 低リン・低粘度であることが報告されている2。.また，リ ン酸基を多く含むものは粘度が高いということが外国産の 馬鈴薯品種由来の澱粉を用いて証明されている31. 粒径で 分画した粒子径の異なる馬鈴薯澱粉が一部の工場で生産さ れているが, 一般的な傾向として, 粒子径が大きいほどリ ン含量が低く，粒子径が小さいほどリン含量が高いことが 判明している

ビールや発泡酒醇造の際には, 副原料の澱粉は加熱処理 を施された後, 麦芽由来の澱粉分解酵素により糖化処理が なされる。馬鈴著澱粉を糖化する際には，リン酸基の近傍 には澱粉分解酵素が作用できず，リン酸基を有するオリゴ 糖が副生成物として生じる ${ }^{\circ}$.リン酸化オリゴ糖は，マル トトリオースからマルトテトラオースにリン酸基が 1 個の 割合で結合した画分 (PO-1 画分) が主成分であるが6,7)，マ イナー成分として，リン酸基が 2 個以上結合した画分 (PO-2 画分) も存在している吕). このようなリン酸化オリ ゴ糖のカルシウム塩には，脂質代謝改善効果 ${ }^{9}$, う蝕予防 効果 ${ }^{10)}$ 等の機能性があることがすでに報告されている。馬 鈴薯澱粉をビールや発泡酒醉造の副原料として用いれば, 麦芽中の澱粉分解酵素によっても切断されずに残ったリン 酸化オリゴ糖は，ビール酵母によっても資化されないた め, リン酸化オリゴ糖がビールや発泡酒内に残り, 機能性 成分に富んだ製品ができる可能性が大きい，副原料の馬鈴 薯澱粉の比率を高くする，または高りン型の馬鈴薯澱粉を 用いれば，さらにリン酸化オリゴ糖を多く含んだ製品がで きると考えられる。一方，馬鈴薯澱粉糊は粘度が高い特性 を有するが, 糖化の際は糊化澱粉となるため, 発泡酒醉造 時に粘度による負荷がかかるといった難点もある。

そこで，本研究では，北海道で大量に生産されている馬 鈴薯澱粉に着目し，澱粉工場製品の中で，特にリン含量が 高く，粘度が比較的低い馬鈴薯澱粉を選定し，このような 馬鈴著澱粉を副原料とした新規の発泡酒の製造を試みた。 なお，比較のために現在工業的に生産されているコーンス ターチ, サツマイモ澱粉を副原料とした発泡酒も製造し た。また，これらのようにして得られた製品の官能評価， 成分評価も行った。

\section{実験材料および方法}

\section{1. 馬鈴薯澱粉原料}

馬鈴著澱粉は，まず斜里町農協中斜里でん粉工場製の風 力分級機を用いて製造された大粒子，小粒子，極小粒子の
澱粉を供試した。また，品種別では，神野でんぷん工場(株) において製造された紅丸，コナフブキ，エニワ，ホッカイ コガネ，農林 1 号，ワセシロの澱粉を用いた。ささらに，東 部十勝農産加工農業組合連合会 (東工連) の標準品を用い た.

\section{2. 澱粉の特性評価}

上記の澱粉についてメジアン径，リン含量，最高粘度を 評価し，醸造用として最適な馬鈴薯澱粉を選定した。澱粉 のメジアン径の測定法はNoda et al ${ }^{11}{ }^{11} の$ 方法に準拠した. また，澱粉のリン含量はリン・バナド・モリブデン酸法 ${ }^{12}$ で行った.ラピッドビスコアナライザー (RVA) による澱 粉粘度特性について Noda et al. ${ }^{11}$ の方法に準拠して澱粉濃 度 $4 \%$ (無水物換算) の条件で測定し, 得られた粘度曲線 から最高粘度を読み取った。

\section{3. 醸造用澱粉}

上記の試験で醸造用として最適と判断された馬鈴著澱粉 を用いた。また，サッマイモ澱粉 (JA 鹿児島きもつき祓 川澱粉工場製)，コーンスターチ (日本食品化工(株)製) を対 照澱粉として用いた。

\section{4. 醸造用他原料}

発泡酒醸造の原料として, 地醸造用麦芽 (ピルスナーモ ルト：カラメルモルト $=20 ： 1)($ アサヒビールモルト(株)製) および酵母として培養酵母ピルスナー（ミュンヘン工科 大，ヴァイエンシュテファンNo. 34) (秋田今野商店(株) 製)，さらにホップとしてテトナングとカスケード (アサ ヒ化学工業(株)製) を用いた。

\section{5. 醸造 試 験}

各種澱粉 $70 \mathrm{~kg}$, 麦芽 $105 \mathrm{~kg}$ ，水 $1.3 \mathrm{~kL}$ である発泡酒に ついて Fig. 1 の要領で製造した。なお，ラガービールは各 種澱粉 $70 \mathrm{~kg}$ の代わりに麦芽を用いることで，麦芽 $100 \%$ とした。

1) 糖化

煮沸釜に用意した $50^{\circ} \mathrm{C}$ の温水 $300 \mathrm{~L}$ に各種澱粉 $70 \mathrm{~kg}$ と麦芽 $20 \mathrm{~kg}$ を溶かした後に加熱し， $70^{\circ} \mathrm{C} て ゙ 15$ 分保った

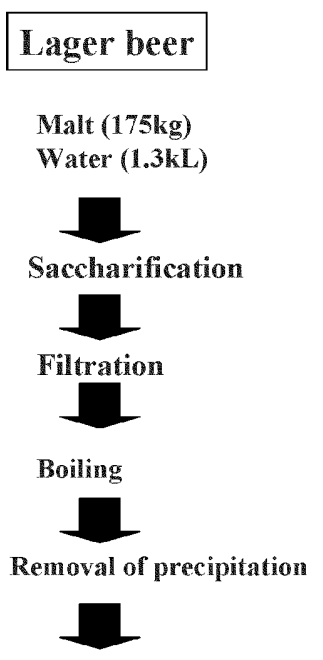

Fermentation

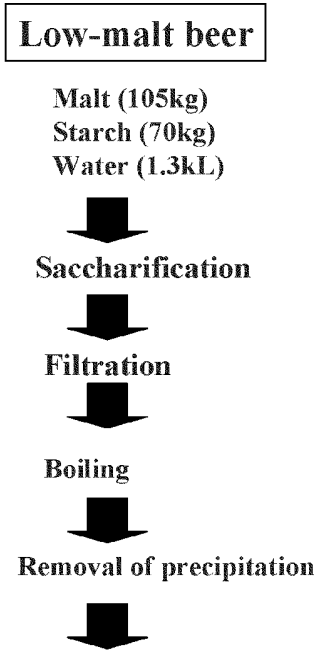

Fermentation
Fig. 1. Brewing process of lager beer and low-malt beer. 
後, $100^{\circ} \mathrm{C}$ で 10 分間保持することにより生澱粉を糊化さ せた。そして，煮沸釡に水 $450 \mathrm{~L}$ と麦芽 $85 \mathrm{~kg}$ を加えて $52^{\circ} \mathrm{C}$ で 15 分間，麦芽由来の酵素によるタンパク質分解を 行った後, 引き続き加熱して $64^{\circ} \mathrm{C} て ゙ 40$ 分糖化し, さらに 加熱して $72^{\circ} \mathrm{C} て ゙ 30$ 分糖化を行うことにより，麦芽および 各種澱粉に由来する糖質を含有する麦汁を得た。なお，ラ ガービールでは, 最初の生澱粉を糊化させる工程を省略し た。

\section{2) 濾過}

1 )で得られた麦汁を濾過槽に移し濾過することによ り，1番麦汁を得た。またこの 1 番麦汁の残渣に温水 (70-80 $\left.{ }^{\circ} \mathrm{C}\right)$ を散水して 2 番麦汁を得た。さらに，この 2 番 麦汁の残渣に温水 $\left(70-80^{\circ} \mathrm{C}\right)$ を散水して 3 番麦汁を得た. 1 番麦汁， 2 番麦汁， 3 番麦汁を混合することにより，粗 糖化液を得た。

3 ) 者沸

2 ) で得られた粗糖化液を煮沸釜で加熱し，90 分間煮 沸した。沸騰すると同時にビターホップとしてテトナング $610 \mathrm{~g}$ を加え, アロマホップとして煮沸開始 60 分後にカ スケード $160 \mathrm{~g}$ ，煮沸終了と同時にカスケード $100 \mathrm{~g}$ を加 え，煮沸を終了した。

4 ) 沈殿除去

3 ) で得られた煮沸後の液をワールプールというタンク に移動させ，モルトジュース中の凝固タンパク質やホップ のカスを高速回転させることによって取り除き，発酵用の 糖化液を得た。

5 ) 発酵

4 ) で得られた糖化液を発酵タンクに移し，培養酵母ピ ルスナーを加えて $5-10^{\circ} \mathrm{C} て ゙ 2$ 週間前後 1 次発酵を行った。

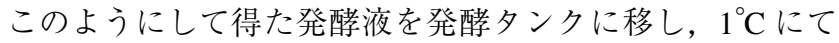
30 日間 2 次発酵を行った. 2 次発酵終了後，瓶詰めを行い 所定の発泡酒を得た。

\section{6. ビール，発泡酒の官能試験・一般成分分析}

試験醸造にて得られた発泡酒，ラガービールの試料につ いて官能評価試験を実施した。官能評価項目は，アロマ (鼻で感じる香り)，外観，フレーバー (口の中で感じる香 り), ボディ (味わいの濃淡表現), 全体印象とした。官能 評価は 5 名のパネラーにより, 各項目 (アロマ=10 点満 点, 外観 $=6$ 点満点，フレーバー $=19$ 点満点，ボディ $=5$ 点 満点, 全体印象 $=10$ 点満点) について不適, 不十分な分を 減点して採点することで行った。 また，BCOJビール分析 法 $^{13)}$ に従い，一般成分の分析を行った。

\section{7. リン酸化オリゴ糖の調製}

リン酸化オリゴ糖標準品は，ポスカム歯科用クリアドラ イ (江崎グリコ(株)製) より精製した。すなわち，粉砕した ポスカム歯科用クリアドライ $248 \mathrm{~g}$ に蒸留水 $300 \mathrm{~mL}$ を加 え，加熱溶解した。この懸濁液を遠心操作 $(8000 \mathrm{rpm}, 30$ 分) で上層画分 (上部にガムが浮遊) と下層画分 (ゼラチ ンが主体) に分けた。上層画分中のガムを回収し，蒸留水 $200 \mathrm{~mL}$ を加えて再び加熱溶解し，遠心操作 (8000 rpm,
30 分) によりガムを除去した。二度の抽出で得られた上 部の液層部を混合した後 (約 $400 \mathrm{~mL}$ )，塩化ナトリウムを $0.2 \mathrm{M}$ になるように加えた。次いで，2.5 倍量のエタノール を加え，室温放置することで沈殿物を回収し，蒸留水 (約 $100 \mathrm{~mL})$ に再溶解した。この溶液にグルコアミラーゼ液 1 $\mathrm{mL}$ (Rhizopus sp 由来, 東洋紡(株製) $(600 \mathrm{U} / \mathrm{mL}), \alpha-ア$ ミ ラーゼ液 $1 \mathrm{~mL}$ (Bacillus subtilis 由来，上田化学(株製) (300 $\mathrm{U} / \mathrm{mL}$ ), プルラナーゼ液 $1 \mathrm{~mL}$ (Aerobacter aerogenes 由来, (株林原生物化学研究所製) $(200 \mathrm{U} / \mathrm{mL})$ を加えて，40ㄷ 6 時間保持することで，ポスカムに添加されているデキス トリンを分解した。 反応終了後，3倍量のエタノールを加 え，室温放置後，遠心操作 (8000 rpm，30 分) により遊離 グルコースなどの夾雑物の除去し沈殿物を回収した。沈殿 物を蒸留水に再溶解した後，薄層クロマトグラフィー ${ }^{14)}$ より純度を確認し，夾雑物が完全に除去できるまでエ夕 ノール沈殿操作を繰り返した。最終的にリン酸化オリゴ糖 に相当するスポットのみが確認できたものについて，室温 乾燥することでリン酸化オリゴ糖の標準品を得た。

\section{8. ビール, 発泡酒のリン酸化オリゴ糖の分析}

リン酸化オリゴ糖の分析は，Carbo Pac PA-100 カラムを 用いたDionex DX-300 システムによるパルスドアンペロ メトリー検出器 (PAD) が装備されている高性能アニオン 交換クロマトグラフィーを用い, Kamasaka et al. ${ }^{6}$ の方法 に準拠して行った。サンプルについては，上記により調製 されたリン酸化オリゴ糖の標準品を蒸留水に溶解したも の，先述の薄層クロマトグラフィーと同様の方法でビー ル，発泡酒原液をエタノール沈殿させ再溶解したものを用 いた。

\section{実験結果および考察}

\section{1. 発泡酒醸造適性を有する馬鈴薯澱粉の選定}

馬鈴薯澱粉の需要拡大を目的として，発泡酒醉造適性を 有する馬鈴薯澱粉の選定を行った．Table 1 に供試した馬 鈴著澱粉製品のリン含量，RVAによる最高粘度およびメ ジアン径の結果を示した。メジアン径は，風力分級機で得

Table 1. Characteristics of potato starches.

\begin{tabular}{lccc}
\hline & $\begin{array}{c}\text { Phosphorus } \\
\text { content } \\
(\mathrm{ppm})\end{array}$ & $\begin{array}{c}\text { Peak } \\
\text { viscosity } \\
(\mathrm{RVU})\end{array}$ & $\begin{array}{c}\text { Median } \\
\text { size } \\
(\mu \mathrm{m})\end{array}$ \\
\hline Large & 756 & 299 & 42.3 \\
Small & 979 & 275 & 21.6 \\
Extremely small & 1125 & 221 & 13.6 \\
Benimaru & 652 & 259 & 46.6 \\
Konafubuki & 777 & 290 & 42.3 \\
Eniwa & 880 & 324 & 42.4 \\
Hokkaikogane & 874 & 312 & 41.6 \\
Norin No. 1 & 654 & 230 & 36.4 \\
Waseshiro & 762 & 260 & 33.3 \\
Standard & 847 & 305 & 35.2 \\
\hline
\end{tabular}


られた大粒子は $42.3 \mu \mathrm{m}$ であったのに対し，小粒子，極小 粒子で，それぞれ $21.6,13.6 \mu \mathrm{m}$ と明らかに小さかった。 一方，品種別扔よび標準品では 33.3-46.6 $\mu \mathrm{m}$ に分布した。 リン含量は，小粒子，極小粒子は，それぞれ979，1125 ppm と高い值を示した。品種別では紅丸および農林 1 号 がそれぞれ 652, $654 \mathrm{ppm}$ と低く，エニワおよびホッカイ コガネが $880 ， 874$ ppm と高かったＲVAによる最高粘度 は，低リン型の紅丸および農林 1 号が低く，高リン型の工 ニワおよびホッカイコガネが高かった。品種別のリン含 量, 最高粘度の結果は, 前報”と同様の傾向がみられた。 極小粒子は，高リン型であるにもかかわらず，最高粘度が 低く，前報 ${ }^{4.5}$ の結果と一致した。

発泡酒醸造適性を有する馬鈴著澱粉の選定では，まず機 能性成分として知られているリン酸化オリゴ糖を高含有す る製品を開発することを視野に入れて，高リン型の馬鈴薯 澱粉であることを重視した。一方，発泡酒醸造時の糖化の 際は糊化澱粉を用いるため, 粘度の低い港粉は, 澱粉糖化 の際における粘度による負荷がかからないので利点があ る。コーンスターチやサッマイモ澱粉とほほ同程度の粒径 である風力分級機で製造された極小粒子の馬鈴著澱粉 ( ジアン径 $13.6 \mu \mathrm{m})$ は高リン型で低粘度であるため, 発泡 酒醸造に望ましいと判断し, 以後の発泡酒の醉造試験に使 用することにした。

\section{2. ビール, 発泡酒の醸造試験, 成分特性}

澱粉を副原料に用いた発泡酒の製造条件にしたがって, 極小粒子の馬鈴著澱粉，サッマイモ澱粉，コーンスターチ を副原料に用いた発泡酒の製造試験を行った。馬鈴著澱粉 は糊化工程中の粘度の上昇は, 反応阻害が起こらないレべ ルにとどまり，糖化後の麦汁はヨウ素反応を示さなかっ た，仕込み終了時の麦汁に異味，異臭はなく，発酵も他の 3 種のビール・発泡酒とほぼ同等に進み, 発酵期間は約 2 週間であった。ビール・発泡酒単体についての絶対評価を 行う記述式の官能評価試験において，馬鈴著澱粉で醸造し た発泡酒は，Table 2 に示すように，サッマイモ澱粉掠よ びコーンスターチで醇造した発泡酒と比べてアロマにおい てやや劣るものの，ボデイに打いて高いスコアが得られ た。また，馬鈴薯澱粉の発泡酒は，評価項目の合計值で は，コーンスターチで醉造した発泡酒と同程度に高く，突 出したオフフレーバーは認められず，発泡酒の原料として 適していることが確認された。

Table 2. Sensory attributes of lager beer and low-malt beer.

\begin{tabular}{ccccccc}
\hline & Aroma & $\begin{array}{c}\text { External } \\
\text { appearance }\end{array}$ & Flavor Body & $\begin{array}{c}\text { Whole } \\
\text { impression }\end{array}$ & Total \\
\hline $\begin{array}{c}\text { Low-malt beer } \\
\text { Potato starch }\end{array}$ & 5 & 5 & 10 & 5 & 6 & 31 \\
$\begin{array}{c}\text { Sweet potato } \\
\text { starch }\end{array}$ & 6 & 5 & 9 & 3 & 4 & 27 \\
Corn starch & 7 & 3 & 13 & 3 & 6 & 32 \\
\hline Lager beer & 4 & 6 & 6 & 5 & 4 & 25 \\
\hline
\end{tabular}

Table 3. Componential characteristics of lager beer and low-malt beer.

\begin{tabular}{lcccc}
\hline & \multicolumn{3}{c}{ Low-malt beer } & \\
\cline { 2 - 4 } & $\begin{array}{c}\text { Potato } \\
\text { starch }\end{array}$ & $\begin{array}{c}\text { Sweet } \\
\text { potato } \\
\text { starch }\end{array}$ & $\begin{array}{c}\text { Corn } \\
\text { starch }\end{array}$ & $\begin{array}{c}\text { Lager } \\
\text { beer }\end{array}$ \\
\hline Brix (\%) & 5.3 & 5.0 & 5.2 & 5.0 \\
Specific gravity & 1.010 & 1.007 & 1.008 & 1.000 \\
$\mathrm{pH}$ & 4.35 & 4.43 & 4.51 & 4.57 \\
Acidity (mL/100 mL) & 25.5 & 20.3 & 25.2 & 25.2 \\
Total sugar $(\%)$ & 3.0 & 1.6 & 1.3 & 1.6 \\
Reducing sugar $(\%)$ & 1.0 & 0.2 & 0.5 & 0.4 \\
Total N (mg/100 mL) & 47.9 & 39.0 & 47.4 & 77.7 \\
Formol N (mg/100 mL) & 11.0 & 13.1 & 13.9 & 34.0 \\
Bitterness unit $(\mathrm{BU})$ & 12.4 & 18.9 & 18.6 & 15.8 \\
Alcohol $(\%)$ & 5.1 & 4.8 & 5.4 & 4.7 \\
Real extract $(\%)$ & 4.3 & 3.0 & 3.4 & 3.3 \\
Fermented ability $(\%)$ & 70.9 & 77.1 & 76.8 & 74.3 \\
\hline
\end{tabular}

各試験ビール・発泡酒について成分分析試験を行い, そ の結果を Table 3 に示した。麦芽 100\%のラガービールと 比べて，馬鈴薯澱粉の発泡酒はホルモール態窒素含量が低 かった。しかし，馬鈴薯澱粉の発泡酒の真性エキス，真性 発酵度は，ラガーと比べて遜色なく，アルコール度数も安 定しており酵母の生育に十分な条件であることが確認でき た. 馬鈴薯澱粉の発泡酒は, 他の 3 種のビール・発泡酒と 比べ，全糖量，還元糖量ともに明らかに高いという特徴が あった

PAD が装備されている高性能アニオン交換クロマトグ ラフィーにより, リン酸化澱粉が分解して生じる機能性物 質であるリン酸化オリゴ糖の分析を行った. Fig. 2 にリン 酸化オリゴ糖の標準品と各試験ビール・発泡酒の高性能ア ニオン交換クロマトチャートを示した。リン酸化オリゴ糖 の標準品に含まれる PO-1 画分，PO-2 画分のピークの保持 時間は，以前の報告(6)とぼ致した。ビール，発泡酒原 液には種々のオリゴ糖が多く含まれるため，大体において PO-1 画分のピークは他のオリゴ糖と重なったが，PO-2 画 分のピークは重ならなかった。馬鈴薯澱粉の発泡酒には PO-2 画分に起因する小さなピーク (保持時間 46.75 分) が 確認され, サツマイモ澱粉の発泡酒ではたぶん PO-2 画分 に起因すると考えられるトレース程度のピーク (保持時間 45.76 分) がみられた。一方，コーンスターチで試作した 発泡酒およびラガービールにおいては，このようなピーク はみられず，リン酸化オリゴ糖がほとんど含まれていない ことが示唆された. 以上の高性能アニオン交換クロマト分 析において, PO-1 画分, PO-2 画分のピーク出現には再現 性があった，PO-1 画分，PO-2 画分の量比は，調製条件に よらずほぼ一定であることが示されている゙。 そここで，馬 鈴薯澱粉およびサツマイモ澱粉の発泡酒，リン酸化オリゴ 糖標準品の既知濃度の溶液において，PO-2 画分のピーク 比率を計算することで, リン酸化オリゴ糖量 (PO-1 画分, PO-2 画分の総量) の大まかな測定を行った。その結果, 


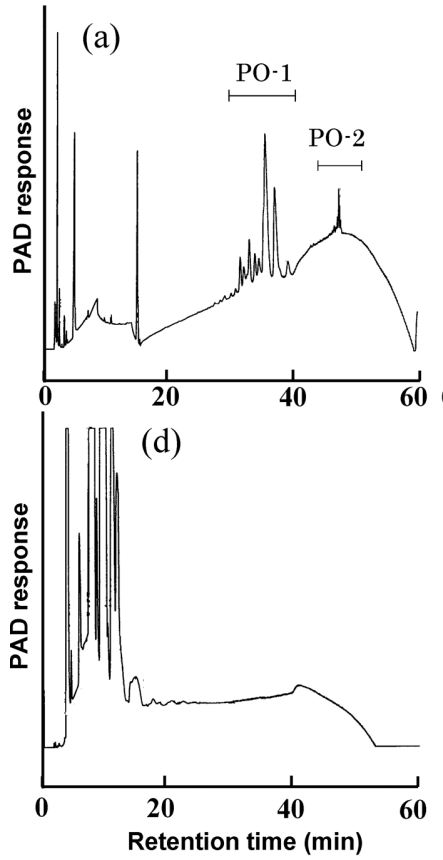

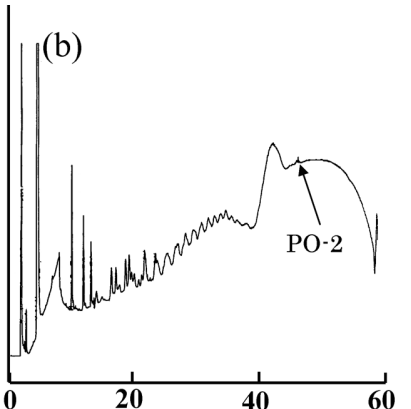

(e) (c)
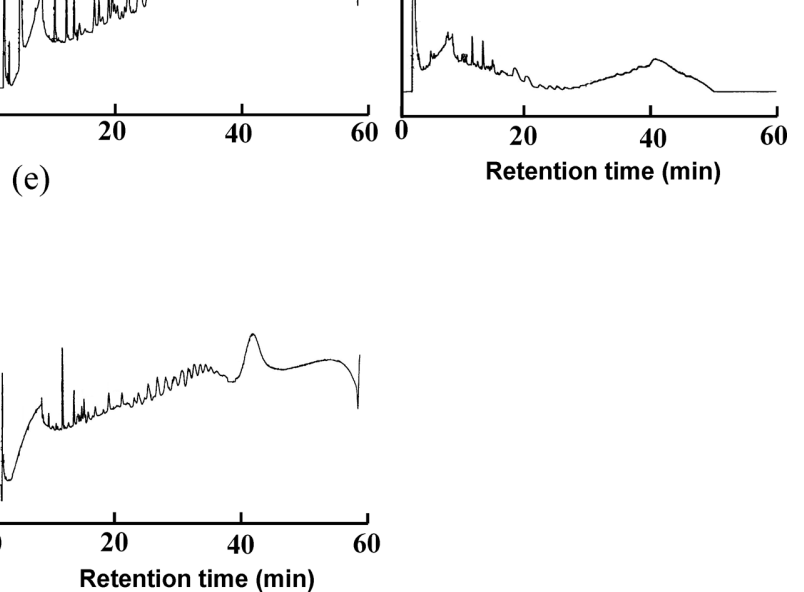

Fig. 2. Chromatograms of the phosphoryl-oligosaccharides of lager beer and low-malt beer.

(a) standard phosphoryl-oligosaccharides, (b) low-malt beer using potato starch, (c) low-malt beer using sweet potato starch, (d) low-malt beer using corn starch, (e) lager beer.

Table 4. Phosphoryl-oligosaccharides content of lager beer and low-malt beer.

\begin{tabular}{lcc}
\hline & $\begin{array}{c}\text { Starch phosphorus } \\
\text { content } \\
(\mathrm{ppm})\end{array}$ & $\begin{array}{c}\text { Phosphoryl- } \\
\text { oligosaccharides } \\
\text { content } \\
(\mathrm{ppm})\end{array}$ \\
\hline Low-malt beer & 1125 & 600 \\
Potato starch & 226 & $<150$ \\
Sweet potato starch & 140 & 0 \\
Corn starch & - & 0 \\
\hline Lager beer & & 0 \\
\hline
\end{tabular}

馬鈴薯港粉の発泡酒では, リン酸化オリゴ糖は $600 \mathrm{ppm}$, サツマイモ澱粉で試作した発泡酒ではきわめて低い濃度 (150 ppm 以下) となった (Table 4).

現在，粒子径ごとに分級された極小粒子の馬鈴著澱粉は 需要が少なく，販路の開拓が大きく求められている．本研 究では, 風力分級機で得られた極小粒子の馬鈴著港粉は発 泡酒の副原料として適性があることを見出し，このような 馬鈴著澱粉で醉造した発泡酒は，他のビール・発泡酒と比 べて，機能性成分であるリン酸化オリゴ糖を含んでいるこ とを明らかにした。本研究結果は，このような安価な澱粉 に高付加価值を付与する意味からも有用性がある．現在， 発泡酒の副原料として使用されているコーンスターチのう ち，ごく一部でも馬鈴著澱粉に取り替わることができれ ば，澱粉原料用の馬鈴著の減産に歯止めをかけることが可 能となる。

本研究は生研センターの異分野融合研究「高度リン酸化 澱粉及びアントシアニンを含有する馬鈴著を用いた機能性 食品の開発」の一環として実施したものである.

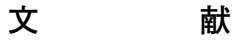

1) S. Hizukuri, S. Tabata and Z. Nikuni: Studies on starch phosphate: Part 1. Estimation of glucose 6-phosphate residues in starch and the presence of tuber bound phosphate(s). Starch/ Stärke, 22, 338-343 (1970).

2 ) T. Noda, S. Tsuda, M. Mori, S. Takigawa, C. Matsuura-Endo, N. Hashimoto and H. Yamauchi: Properties of starches from several potato varieties grown in Hokkaido. J. Appl. Glycosci., 51, 241-246 (2004).

3 ) D.P. Wiesenborn, P.H. Orr, H. H. Casper and B.K. Tacke: Potato starch paste behavior as related to some physical/chemical properties. J. Food Sci., 59, 644-648 (1994).

4 ) 貝沼圭二，山本和夫，鈴木繁男，高谷友久，不破英次：澱 粉の構造と特性に関する研究 (第 4 報) 分級馬鈴薯澱粉の 構造および利用特性. 澱粉科学, 25, 3-11 (1978).

5 ) T. Noda, S. Takigawa, C.M.-Endo, S.-J. Kim, N. Hashimoto, H. Yamauchi, I. Hanashiro and Y. Takeda: Physicochemical properties and amylopectin structures of large, small and extremely small potato starch granules. Carbohydr. Polym., 60, 245-251 (2005).

6 ) H. Kamasaka, M. Uchida, K. Kusaka, K. Yoshikawa, K. Yamamoto, S. Okada and T. Ichikawa: Inhibitory effect of phosphorylated oligosaccharides prepared from potato starch on the formation of calcium phosphate. Biosci. Biotechnol. Biochem., 8, 1412-1416 (1995).

7 ) H. Kamasaka, K. To-o, K. Kusaka, T. Kuriki, T. Kometani, H. Hayashi and S. Okada: The structures of phosphoryl oligosaccharides prepared from potato starch. Biosci. Biotechnol. Biochem., 61, 238-244 (1997).

8 ) H. Kamasaka, K. To-o, K. Kusaka, T. Kuriki, T. Kometani and S. Okada: A way of enhancing the inhibitory effect of phosphoryl oligosaccharides on the formation of calcium phosphate precipitate by using the coupling reaction of cyclomaltodextrin glucanotransferase. J. Appl. Glycosci., 44, 285-293 (1997).

9 ) K. To-o, H. Kamasaka, T. Nishimura, T. Kuriki, S. Saeki and Y. Nakabou: Bioavailability of calcium-bound phosphoryl oligosaccharides in rats. J. Appl. Glycosci., 49, 159-165 (2002).

10）釜阪 寛，今井 奨，西村隆久，栗木 隆，西沢俊樹：馬 鈴薯デンプン由来リン酸化オリゴ糖のミュータンスレンサ 
球菌への影響. 口腔衛生会誌, 52, 66-71 (2002).

11) T. Noda, S. Tsuda, M. Mori, S. Takigawa, C. Matsuura-Endo, K. Saito, W.H.A. Mangalika, A. Hanaoka, Y. Suzuki and H. Yamauchi: The effect of harvest date on starch properties in various potato cultivars. Food Chem., 86, 119-125 (2004).

12) 山本和夫：「生化学実験法 19 澱粉·関連糖質実験法」, 中村道徳, 貝沼圭二編, 学会出版センター, 東京, pp. 3233 (1986).

13) ビール酒造組合：「BCOJ ビール分析法 第 91 巻」, 日本醸 造協会, 東京, p. 241 (1996).

14) K. Saito, K. Kondo, I. Kojima, A. Yokota and F. Tomita: Purification and characterization of 2, 6- $\beta$-D-fructan 6levanbiohydrolase from Streptomyces exfoliatus F 3-2. Appl. Environ. Microbiol., 66, 252-256 (2000).
極小粒子馬鈴薯澱粉を利用した発泡酒の製造と性質

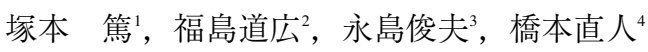

齋藤勝一 ${ }^{4}$, 野田高弘 ${ }^{4}$

${ }^{1}$ 十勝ビール株式会社

(080-0011 带広市西 1 条南 9 丁目 6 番)

2 国立大学法人带広畜産大学

(080-8555 带広市稲田町西 2 線 11 番地)

3 東京農業大学生物産業学部

(099-2493 網走市八坂 196 番地)

${ }^{4}$ 独立行政法人農業食品産業技術総合研究機構

北海道農業研究センター芽室研究拠点

(082-0081 北海道河西郡芽室町新生南 9 線 4 番地)

馬鈴著澱粉を副原料とした新規の発泡酒を製造するため

に，まず，品種および粒径の異なる数種の馬鈴著澱粉の中 から発泡酒醸造適性を有するものを選定した。また，この ようにして得られた発泡酒の成分特性を評価した，馬鈴薯 澱粉工場の 10 種類の製品について澱粉特性を検討した結 果, 風力分級機によって得られた極小粒子澱粉 (メジアン 径 $13.6 \mu \mathrm{m})$ は，リン含量が高いが，RVAによる最高粘度 は低いので, 発泡酒の副原料として最適であると判断し た.リン酸化澱粉が分解して生じるリン酸化オリゴ糖の分 析の結果, このような馬鈴著澱粉で醉造した発泡酒に明ら かにその存在が認められた (600 ppm). 一方, コーンス ターチおよびサッマイモ澱粉で醸造した発泡酒では, リン 酸化オリゴ糖はほとんど認められなかった。 